\title{
Assessing extreme droughts in Spain during 1750-1850 from rogation ceremonies
}

\author{
F. Domínguez-Castro ${ }^{1}$, P. Ribera ${ }^{2}$, R. García-Herrera ${ }^{3}$, J. M. Vaquero ${ }^{4}$, M. Barriendos ${ }^{5}$, J. M. Cuadrat $^{6}$, and \\ J. M. Moreno ${ }^{7}$ \\ ${ }^{1}$ Departamento de Física, Universidad de Extremadura, Badajoz, Spain \\ ${ }^{2}$ Departamento de Sistemas Físicos, Químicos y Naturales, Universidad Pablo de Olavide, Sevilla, Spain \\ ${ }^{3}$ Departamento de Física de la Tierra II, Facultad de Ciencias Físicas, Universidad Complutense de Madrid y Instituto de \\ Geociencias, CISC/UCM, Madrid, Spain \\ ${ }^{4}$ Departamento de Física, Universidad de Extremadura, Mérida, Spain \\ ${ }^{5}$ Department of Modern History, University of Barcelona, Barcelona, Spain \\ ${ }^{6}$ Departamento de Geografía, Universidad de Zaragoza, Zaragoza, Spain \\ ${ }^{7}$ Centro de Estudios del Estado de Feria, Zafra, Spain
}

Correspondence to: F. Domínguez-Castro (f.dominguez@gmail.com)

Received: 21 October 2011 - Published in Clim. Past Discuss.: 23 November 2011

Revised: 13 March 2012 - Accepted: 19 March 2012 - Published: 2 April 2012

\begin{abstract}
Among the different meteorological hazards, droughts are those with the highest socio-economical impact on the Iberian Peninsula. Drought events have been largely studied in the instrumental period, but very little is known about the characteristics of droughts in the preinstrumental period. In this work, several series of rogation ceremonies are used to identify severe droughts within the period 1750 1850. The overlapping of the rogation series with some instrumental series served to identify some climatic characteristics of rogation ceremonies: (a) during spring, rainfall deficits needed to celebrate rogation ceremonies are smaller than in any other season; (b) the hydrological deficit in a particular region increases with the number of locations celebrating rogations simultaneously.

On the other hand, it was found that between 1750-1754 and 1779-1783 are probably the driest periods of the 101 analyzed years. Both show an important number of rogations all over Iberia and during all the seasons.

The most extended drought of this period occurred during the spring of 1817 , affecting 15 of the 16 locations studied. This drought was influenced by the Tambora eruption (1815). The study of the climate footprint of this eruption and its comparison with similar situations in the series suggest that the spring drought of 1824 may be associated with the eruptions of the Galunggung and Usu volcanoes (1822). Further studies are required to confirm this fact and understand the atmospheric mechanisms involved.
\end{abstract}

\section{Introduction}

Droughts are the worst meteorological hazard for the development of human societies. The World Meteorological Organization estimated that during the period 1967-1991, droughts affected $50 \%$ of the 2.8 billion people who suffered from weather-related disasters. Moreover, 1.3 million of the 3.5 million people killed by disasters were due to the direct and indirect effect of droughts (Obasi, 1994).

Historically, some societies have disappeared due to the effect of long lasting droughts (deMenocal, 2001; Nicoll, 2004; Drysdale et al., 2006). Good examples are the collapse of the Acadian Empire, caused by an increase in aridity conditions around 2200 BC (Weiss et al., 1993; Cullen et al., 2000); the collapse of the classic Mayan civilization around $750-900 \mathrm{AD}$ due to a long lasting period, around 200 years, of persistent droughts (Hodell et al., 1995, 2001, 2007; Curtis and Hodell, 1996; Haug et al., 2003).

In recent times, important droughts are referenced all around the world: the Greater Horn of Africa from 1998 to 2005 with 11 million people at risk of starvation (FEWSNET, 2005a,b, 2006a,b; Kijazi and Reason, 2009). In 2005, the Amazon basin experienced the worst drought in nearly 60 years, with the lowest records of water levels in the Amazon (Marengo et al., 2008). In 2010, the drought in the Amazon basin was even more acute than in 2005 (Lewis et al., 2011). In 2006-2007 a severe to extreme drought was 
recorded across large regions of western United States, as well as in the Southern Plains (Dong et al., 2011). Since 1997, Southeast Australia has been gripped by the most severe drought in the last 120 years, the so-called "Big Dry" (Murphy and Timbal, 2008). At the time of writing this paper, the Great Horn is suffering a new dry episode (WMO, 2012), probably associated to La Niña conditions.

Spain is one of the European countries with a higher risk of drought due to the high variability in the temporal and spatial distribution of the precipitation (Esteban-Parra et al., 1998; Serrano et al., 1999; Lana and Burgueño, 2000). In Spain, the longest drought in the last 75 years was recorded between 1990 and 1995, affecting mostly the south and the centre of the country. During these years nearly 12 million people suffered from water scarcity, agricultural production losses were estimated at 1 billion Euros, hydroelectric production drop about $14.5 \%$ and the area affected by fires increased $63 \%$ in the southern half of the country.

On the other hand, projections about future droughts in the Mediterranean area are particularly alarming. A notable increment in the frequency of severe droughts is expected by the end of the 21 st century due to increasing temperatures and decreasing precipitation rates, particularly during spring and summer; the Iberian Peninsula being among the most affected areas (Diffenbaugh et al., 2007). By the end of the 21 st century, over these same areas, return periods of 100 years are expected to be reduced to only 10 years (Weiß et al., 2007).

Droughts have caused in the past and are expected to cause in the future notable ecologic, economic and human losses. In Spain, many authors have studied this phenomenon (Pérez-Cueva and Escrivá, 1982; Martín-Vide and Gomez, 1999; Estrela et al., 2000; Olcina, 2001; Paredes et al., 2006; Vicente-Serrano and López-Moreno, 2006; Lana et al., 2008; Sousa et al., 2010). Most of these studies analyze instrumental data covering the last 50 years and very rarely the last century (Vicente Serrano, 2006a,b; Gallego et al., 2011), but these periods are too short to correctly understand and interpret the variability and trends observed. Thus, longer periods of analysis are needed to analyze secular variations in drought occurrence (Lana and Burgueño, 2000; Huntington, 2006; Trenberth et al., 2007).

Rogation series have shown a significant potential to study the frequency and intensity of droughts in the preinstrumental period in different areas of the Iberian Peninsula (Álvarez-Vázquez, 1986; Martín-Vide and Barriendos, 1995; Barriendos, 1997; Zamora, 2002; Vicente-Serrano and Cuadrat, 2007; Domínguez-Castro et al., 2008). However, it is only in the recent paper by Domínguez-Castro et al. (2010) that regional variability patterns of drought occurrence for the complete Iberian Peninsula have been analyzed during the pre-instrumental period 1600-1750.

This paper analyzes the extreme drought in Spain from 1750 to 1850 . In order to do it, new rogation series have been collected and some previously existing series have been improved with the inclusion of new documentation. Additionally, instrumental and observational series, partially covering the analyzed period, have been used to better understand the climatic signal in rogation series.

\section{Study period}

In Dominguez-Castro et al. (2010), the spatial pattern of droughts in the Iberian Peninsula was studied between 1600 and 1750 because that period was considered the most homogeneous in records from 10 rogation series. These series presented a notable reduction in the number of celebrations recorded during the 19th century. In this paper, new documentary sources have been included and the period 17501850 is studied from 16 rogation series. Additionally, the existence of simultaneous instrumental series within the analyzed period can help to better understand the linkage of the climatic signal of the rogation series with the existence of meteorological and/or agrarian droughts, thus improving the interpretation of previous results.

The period analysed in this paper (1750-1850) is quite interesting not only because it is a pre-industrial period, without anthropogenic forcing, but because it includes the Dalton minimum (1790-1820, a minimum in solar activity, see Vaquero, 2007) and, additionally, it includes one of the most intense volcanic eruptions in recent centuries, the Tambora eruption in 1815 (Stothers, 1984).

On the other hand, it is important to keep in mind that, even when the number of available rogation series is higher than in Domínguez-Castro et al. (2010) and that new instrumental and observational records have been added to the analysis, the studied period was very unstable politically and changes in agricultural procedures and ecclesiastical administration were continuous in these years, which have some influence on the rogation series.

After the battle of Trafalgar (1805), the Spanish army could no longer defend its transoceanic empire, which leaded to an important economic crisis. A transition from an absolute monarchy towards a more liberal state started, reducing considerably the power of the Church in Spain. During the Independence War (1808-1814), the Church suffered from the transformation started by Jose Bonaparte and its influence in socio-political decisions was highly reduced. Later, during the Liberal Triennia (1820-1823), the ecclesiastical influence was even more reduced. Jesuits were expelled from Spain and the Inquisition was suppressed (1820). Later, in 1837 , the tithe was also suppressed and a compulsory expropriation of lands and possessions of the Church was performed between 1836 and 1841 .

No technical modifications are appreciable in agriculture along the analysed period, in fact, according to Moral Ruiz (1979), the agrarian techniques in Spain were practically identical to those from a century before. However, some modifications in the way agriculture was managed in 
Spain were introduced during these years with an agrarian reform in the Iberian Peninsula, with three new and specialized models in different areas of the Iberian Peninsula (Yoshiyuki Kondo, 1983):

- Septentrional model: stagnation of wheat production; increasing corn production and increasing production of "lower value crops" (mainly for self use).

- Interior model: great expansion in the production of cereals, especially wheat.

- Mediterranean model: increasing specialization in the production of highly commercial crops like grapes. Wheat production is restrained.

All these political and agrarian uncertainties lead us to interpret our data very carefully, keeping in mind that whenever rogations were celebrated, it is sure that a hydrological deficit was present but that if no rogation was celebrated, we can not be certain that there was no hydrological deficit, since social or economic conditions could be present that prevented the celebration or necessary rogations. Of course, these considerations are particularly important for low intensity droughts, while it is known that during the most severe droughts, rogation ceremonies were celebrated whatever the socio-economic conditions were. This is the reason why this paper is centered in extreme droughts which will be identifiable from the high number of rogations celebrated

\section{Data}

\subsection{Rogation ceremonies series}

A rogation is a public pray performed in order to obtain from God a solution for a severe adverse meteorological situation that makes normal crop development impossible. Rogations were celebrated either to ask for rain (pro pluvia), or to ask for a stop in the rain (pro serenitate or pro remissione). In this study we have worked only with rogations pro pluvia in order to characterize situations with a lack of precipitation: droughts.

Rogations considered as a climatic proxy have been widely used in both Iberian countries: Spain (ÁlvarezVázquez, 1986; Martín-Vide and Barriendos, 1995; Barriendos, 1997; Zamora, 2002; Vicente-Serrano and Cuadrat, 2007; Domínguez-Castro et al., 2008, 2010) and Portugal (Alcoforado et al., 2000; Taborda et al., 2004). They have been used combined with other proxies at European level (Luterbacher et al., 2002; Pauling et al., 2006; Camuffo et al., 2011).

The main characteristics to consider when this kind of study is performed are:

- It is a proxy for agrarian droughts and, thus, it is not only determined by meteorological conditions but by other factors as soil quality, type of crop, etc.
- It is a social proxy influenced by subjective human decisions about when a rogation is needed and what kind of liturgical act is to be performed, even when meteorological conditions are always the key factor to begin with a rogation (Domínguez-Castro et al., 2008).

- Seasonality is an important factor when its frequency is analysed. Rogations are a response to agrarian droughts and these droughts are much more frequent in those seasons when crops are more sensitive to meteorological conditions. In the Iberian Peninsula, a little decrease in the precipitated water during spring or, simply, a bad temporal distribution of the precipitation during this season, can produce a severe reduction in crop production. This situation is very different during summer, when in certain regions, a lack of precipitation can produce no effect at all in the production of many of the traditional crops and rogation would only be celebrated when a scarcity of water can affect livestock or human comfort. In consequence, in the Iberian Peninsula, spring is the season when rogations are more frequent followed by autumn and winter, the celebrations being scarce during the summer.

- It is a high resolution proxy. The exact date of the celebration of the rogation is always known, even when the administrative character of these processes leads to a lag of 3 or 4 days between the moment when the farmer notices that a rogation is needed and the actual celebration (Martín-Vide and Barriendos, 1995; Domínguez-Castro et al., 2008). This is not a critical problem when rogation series are used to identify droughts but should be carefully considered if pro-serenitate rogations were analyzed.

- Spatial coverage: in Spain, all the villages, towns or cities with a well preserved ecclesiastical or civil register are candidates to generate a rogation series, but the extraction of these series is highly time-consuming due to the great amount of administrative documentation that has to be read and checked.

In this study we have worked with 16 rogation series (Fig. 1), all of them cover the period 1750-1850. Table 1 includes the archives and sources consulted to create the series. Details of the documentary sources used to elaborate the three new series (Calahorra, Teruel and Zafra) can be consulted in Appendix A.

\subsection{Precipitation series}

In Spain there are only three instrumental precipitation series in the literature overlapping with the period analysed here during a long enough period.

- Barcelona: in 1780, Dr. F. Salvá began a series of observations using the methods of Cotte and Javeour. The 
Table 1. Archives and sources consulted to generate the rogation series. For the details of the documentary sources consulted for Calahorra, Teruel and Zafra see Appendix A.

\begin{tabular}{|c|c|c|c|}
\hline Location & Archive & Source & References \\
\hline $\begin{array}{l}\text { Bilbao } \\
43^{\circ} 15^{\prime} 25^{\prime \prime} \mathrm{N} \\
02^{\circ} 55^{\prime} 25^{\prime \prime} \mathrm{W}\end{array}$ & Townhall & $\begin{array}{l}\text { City Council Acts } \\
\text { Local Histories }\end{array}$ & Rodrigo and Barriendos (2008) \\
\hline $\begin{array}{l}\text { Santo Domingo } \\
\text { de la Calzada } \\
42^{\circ} 26^{\prime} 31^{\prime \prime} \mathrm{N} \\
02^{\circ} 57^{\prime} 09^{\prime \prime} \mathrm{W}\end{array}$ & Cathedral & $\begin{array}{l}\text { Chapter Acts } \\
\text { Cathedral accounts }\end{array}$ & Sáez de Ocáriz (1990) \\
\hline $\begin{array}{l}\text { Calahorra } \\
42^{\circ} 18^{\prime} 12^{\prime \prime} \mathrm{N} \\
01^{\circ} 57^{\prime} 53^{\prime \prime} \mathrm{W}\end{array}$ & Cathedral & Chapter Acts & This work \\
\hline $\begin{array}{l}\text { Girona } \\
41^{\circ} 59^{\prime} 04^{\prime \prime} \mathrm{N} \\
02^{\circ} 49^{\prime} 31^{\prime \prime} \mathrm{E}\end{array}$ & Townhall & $\begin{array}{l}\text { City Council Acts } \\
\text { Private Diaries } \\
\text { Local histories }\end{array}$ & $\begin{array}{l}\text { Martin-Vide and Barriendos } \\
\text { (1995) }\end{array}$ \\
\hline $\begin{array}{l}\text { Vic } \\
41^{\circ} 55^{\prime} 50^{\prime \prime} \mathrm{N} \\
02^{\circ} 15^{\prime} 13^{\prime \prime} \mathrm{E}\end{array}$ & $\begin{array}{l}\text { Townhall } \\
\text { Cathedral }\end{array}$ & $\begin{array}{l}\text { City Council Acts } \\
\text { Chapter Acts }\end{array}$ & $\begin{array}{l}\text { Martin-Vide and Barriendos } \\
\text { (1995) }\end{array}$ \\
\hline $\begin{array}{l}\text { Barcelona } \\
41^{\circ} 22^{\prime} 58^{\prime \prime} \mathrm{N} \\
02^{\circ} 10^{\prime} 37^{\prime \prime} \mathrm{E}\end{array}$ & $\begin{array}{l}\text { Townhall } \\
\text { Catedral } \\
\text { Kingdom's } \\
\text { Archive }\end{array}$ & $\begin{array}{l}\text { City Council Acts } \\
\text { Chapter Acts } \\
\text { Kingdom's chronicles } \\
\text { Private Diaries }\end{array}$ & $\begin{array}{l}\text { Martin-Vide and Barriendos } \\
\text { (1995); Barriendos (1997); } \\
\text { Rodrigo and Barriendos (2008) }\end{array}$ \\
\hline $\begin{array}{l}\text { Cervera } \\
41^{\circ} 39^{\prime} 56^{\prime \prime} \mathrm{N} \\
01^{\circ} 16^{\prime} 14^{\prime \prime} \mathrm{E}\end{array}$ & County Archive & $\begin{array}{l}\text { City Council Acts } \\
\text { Chapter Acts }\end{array}$ & $\begin{array}{l}\text { Martin-Vide and Barriendos } \\
\text { (1995) }\end{array}$ \\
\hline $\begin{array}{l}\text { Tarragona } \\
41^{\circ} 07^{\prime} 09^{\prime \prime} \mathrm{N} \\
01^{\circ} 15^{\prime} 28^{\prime \prime} \mathrm{E}\end{array}$ & $\begin{array}{l}\text { Townhall } \\
\text { Departamental } \\
\text { Archive } \\
\text { Bishopric }\end{array}$ & $\begin{array}{l}\text { City Council Acts } \\
\text { Chapter Acts } \\
\text { Private Diaries }\end{array}$ & $\begin{array}{l}\text { Martin-Vide and Barriendos } \\
\text { (1995) }\end{array}$ \\
\hline $\begin{array}{l}\text { Tortosa } \\
40^{\circ} 48^{\prime} 50^{\prime \prime} \mathrm{N} \\
00^{\circ} 31^{\prime} 19^{\prime \prime} \mathrm{E}\end{array}$ & $\begin{array}{l}\text { Townhall } \\
\text { Cathedral }\end{array}$ & $\begin{array}{l}\text { City Council Acts } \\
\text { Chapter Acts }\end{array}$ & $\begin{array}{l}\text { Martin-Vide and Barriendos } \\
\text { (1995) }\end{array}$ \\
\hline $\begin{array}{l}\text { Zaragoza } \\
41^{\circ} 38^{\prime} 60^{\prime \prime} \mathrm{N} \\
00^{\circ} 52^{\prime} 60^{\prime \prime} \mathrm{W}\end{array}$ & $\begin{array}{l}\text { Townhall } \\
\text { Cathedral } \\
\text { Basilica of } \\
\text { Our Lady of } \\
\text { the Pillar }\end{array}$ & $\begin{array}{l}\text { City Council Acts } \\
\text { Chapter Acts }\end{array}$ & $\begin{array}{l}\text { Cuadrat and Vicente Serrano } \\
\text { (2002); Vicente-Serrano and } \\
\text { Cuadrat (2007) }\end{array}$ \\
\hline $\begin{array}{l}\text { Teruel } \\
40^{\circ} 20^{\prime} 37^{\prime \prime} \mathrm{N} \\
01^{\circ} 06^{\prime} 26^{\prime \prime} \mathrm{W}\end{array}$ & Catedral & Chapter Acts & This work \\
\hline $\begin{array}{l}\text { Zamora } \\
41^{\circ} 29^{\prime} 56^{\prime \prime} \mathrm{N} \\
05^{\circ} 45^{\prime} 16^{\prime \prime} \mathrm{W}\end{array}$ & Cathedral & Chapter Acts & Rodrigo and Barriendos (2008) \\
\hline $\begin{array}{l}\text { Toledo } \\
39^{\circ} 51^{\prime} 25^{\prime \prime} \mathrm{N} \\
04^{\circ} 01^{\prime} 25^{\prime \prime} \mathrm{W}\end{array}$ & $\begin{array}{l}\text { Cathedral } \\
\text { Townhall }\end{array}$ & $\begin{array}{l}\text { Chapter Acts } \\
\text { City Council Acts } \\
\text { Private Diaries }\end{array}$ & $\begin{array}{l}\text { Barriendos (1997); Dominguez- } \\
\text { Castro et al. (2008); Rodrigo and } \\
\text { Barriendos (2008) }\end{array}$ \\
\hline $\begin{array}{l}\text { Zafra } \\
38^{\circ} 25^{\prime} 20^{\prime \prime} \mathrm{N} \\
06^{\circ} 25^{\prime} 05^{\prime \prime} \mathrm{W}\end{array}$ & $\begin{array}{l}\text { Townhall } \\
\text { Convent of } \\
\text { Santa Clara } \\
\text { Basilica of } \\
\text { Candelaria }\end{array}$ & $\begin{array}{l}\text { City Council Acts } \\
\text { Local histories }\end{array}$ & This work \\
\hline $\begin{array}{l}\text { Sevilla } \\
37^{\circ} 23^{\prime} 08^{\prime \prime} \mathrm{N} \\
05^{\circ} 59^{\prime} 35^{\prime \prime} \mathrm{W}\end{array}$ & $\begin{array}{l}\text { Townhall } \\
\text { Cathedral }\end{array}$ & $\begin{array}{l}\text { Chapter Acts } \\
\text { City Council Acts } \\
\text { Local histories }\end{array}$ & $\begin{array}{l}\text { Barriendos et al. (1997); Rodrigo } \\
\text { and Barriendos (2008) }\end{array}$ \\
\hline $\begin{array}{l}\text { Murcia } \\
37^{\circ} 59^{\prime} 02^{\prime \prime} \mathrm{N} \\
01^{\circ} 07^{\prime} 43^{\prime \prime} \mathrm{W}\end{array}$ & $\begin{array}{l}\text { Townhall } \\
\text { Cathedral }\end{array}$ & $\begin{array}{l}\text { Chapter Acts } \\
\text { City Council Acts } \\
\text { Local histories }\end{array}$ & $\begin{array}{l}\text { Barriendos et al. (1997); Rodrigo } \\
\text { and Barriendos (2008) }\end{array}$ \\
\hline
\end{tabular}




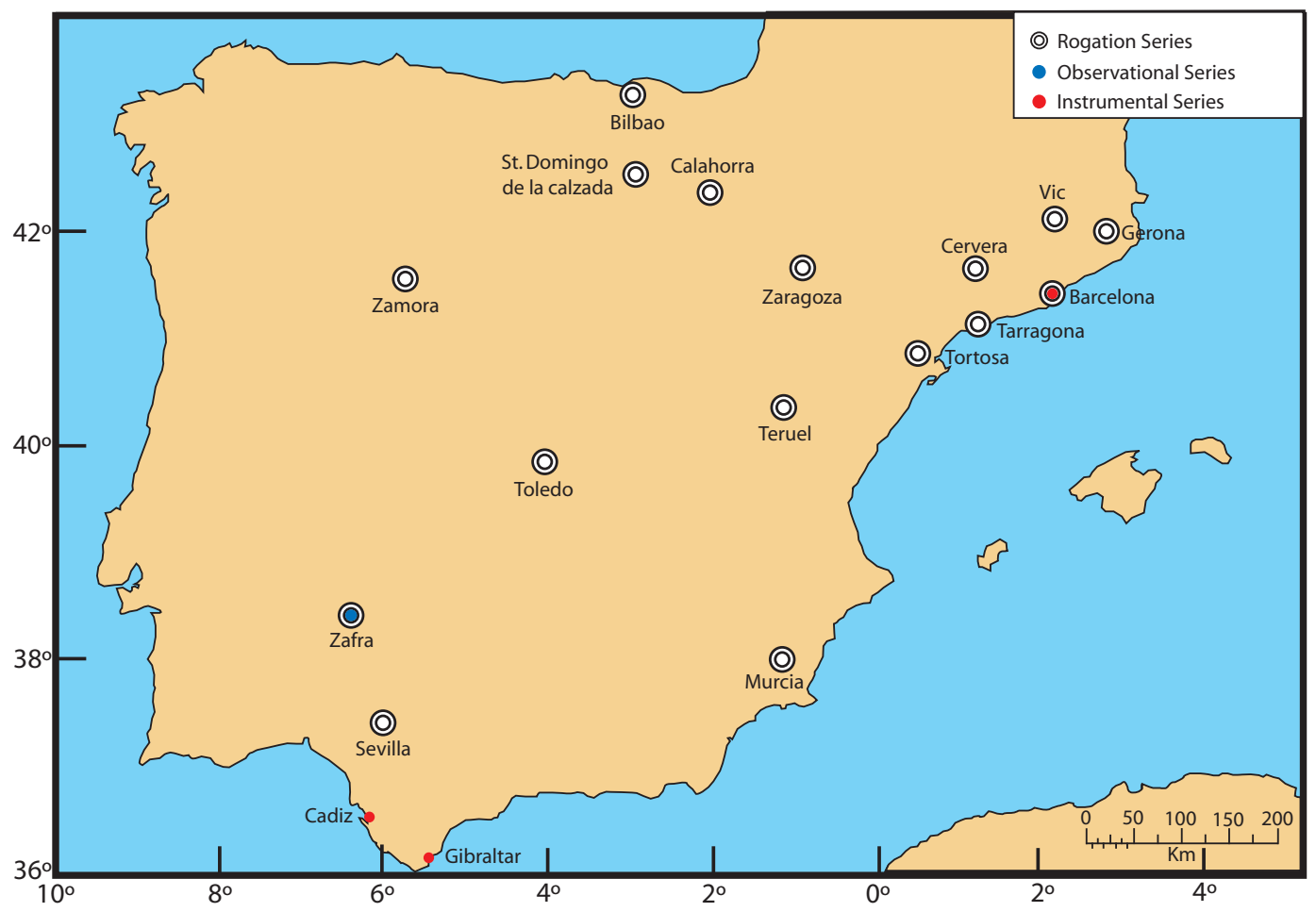

Fig. 1. Location of the rogation observational and instrumental series.

series includes monthly precipitation beginning in 1786 (Barriendos et al., 1997).

- Cadiz: the Observatory of the Navy was built in San Fernando (6 km away from Cadiz) in 1798. They produced meteorological observations from the beginning and continue till today. A monthly precipitation series is available since 1805 (Barriendos et al., 2002).

- Gibraltar: precipitation measurements began in 1790 in order to better administrate the water supply in the city, particularly for those years when a conflict stopped the water supply from inland (Wheeler, 2007).

In addition to instrumental data, another series with observational data and with a good enough resolution are available. The Feria Index rebuilds the evolution of monthly precipitation in Zafra from the weekly correspondence between the Duke of Feria and his major in the Duke's Lands in Zafra during the period 1750-1840, with small gaps in 1765 and 1810 (Fernández-Fernández et al., 2011).

\section{Comparison between observational and rogation series}

Taking into account the characteristics of the rogation ceremonies as climate proxy describes above, a situation in a certain location is considered as dry whenever a rogation is celebrated there. The number of rogations and the liturgy associated with every rogation have not been considered, because they could be sources of additional uncertainty (Dominguez-Castro et al., 2008). Using the instrumental and observational precipitation series, differences between rogations celebrated in different seasons and droughts affecting one or more locations will be studied in detail. This analysis will be possible in two areas where observational and rogation series coincide during a long enough period: northeastern coast and south-western area.

\subsection{North-eastern coast region}

Figure 2 includes the evolution of the rogation series in Gerona, Barcelona, Tarragona and Tortosa between 1750 and 1850 , and the instrumental precipitation series in Barcelona between 1786 and 1850. Within the analyzed period, agricultural uses in all these areas evolved in a similar way (Yoshiyuki Kondo, 1983). Figure 2 shows the seasonal anomalies in precipitation for the period 1786-1850 in Barcelona and, as colour bars, the years when one or more rogations were celebrated.

From Fig. 2 it is possible to see that during summer, autumn and winter, almost all the rogations occur during years characterized by a negative anomaly of the precipitation, while in spring, there is a notable number of years with rogations and precipitation higher than normal. On the other hand, it is noteworthy that the years with rogations in many sites are characterized by a very low precipitation. In winter, 

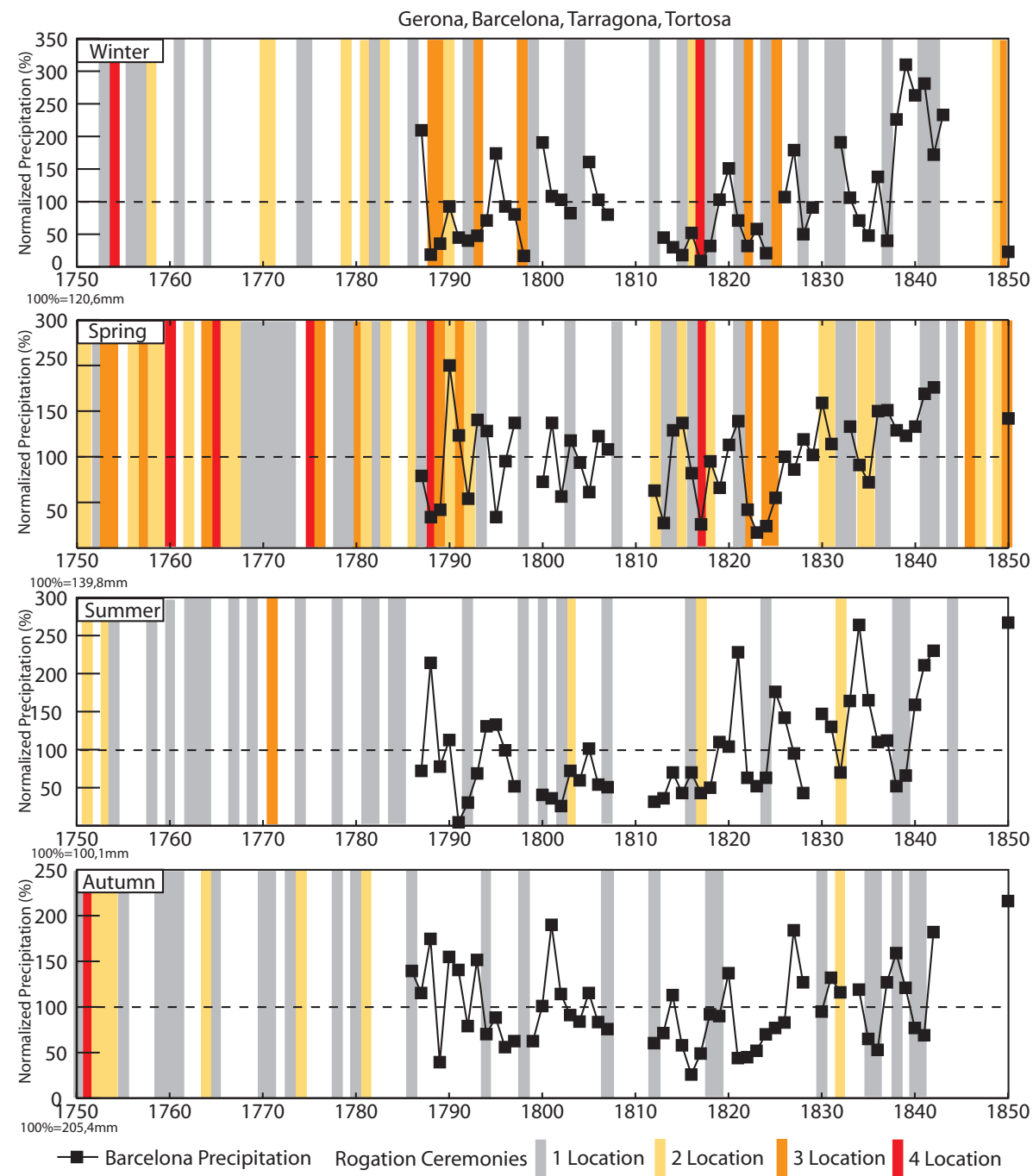

Fig. 2. North-eastern coast region. Line: seasonal anomaly of the precipitation in Barcelona. Bars: number of sites where rogations were celebrated (red: 4 sites, darker orange: 3 sites; yellow: 2 sites; and grey: 1 site; Gerona, Barcelona, Tarragona and Tortosa).

the only drought that affected the four sites (1817) is characterized by the lowest precipitation in Barcelona. A very similar situation occurs in spring of the two years with rogations in the four sites (1788 and 1817). Both are among the driest years of the series.

Table 2 shows the mean anomaly in the precipitation series of Barcelona for those years with rogations being celebrated during the same year and season in 1,2, 3 or 4 of the analysed sites. It also includes seasonal information about the number of years when a negative anomaly of the precipitation (precipitation that year below long term mean precipitation) coincides with the celebration of rogations and the number of years when a positive anomaly coincides with rogation celebrations.

Results shown in Fig. 2 and Table 2 can help us to better interpret the meaning of a regional drought identified from the celebration of rogations in one or more locations simultaneously and about the intensity of these droughts.

It can be observed that it is during spring when the celebration of rogations is associated with the highest anomalies in mean precipitation. It is not obvious how to interpret this fact. When a drought has a more local character, identified in one or two sites, the precipitation was higher than normal ( $122.9 \%$ and $109.5 \%$ respectively). It has to be kept in mind that rogations in spring are proxies of agrarian droughts and are celebrated when the lack of precipitation is affecting the crop growth. This lack of precipitation is important mainly when cereals are in the grand growth period, when their water requirement is maximum and the plant is most sensitive to the water availability. That is the reason why, at a local scale, it is possible to have records of rogations even in years when the mean seasonal precipitation has been higher than normal, 
Table 2. Columns 1 and 2 include the number of years when a rogation is celebrated when less $(<100 \%)$ or more $(>100 \%)$ precipitation than long term precipitation mean value. Column 3 includes precipitation mean anomaly in Barcelona for years with rogations celebrated simultaneously in 1 to 4 locations (Gerona, Barcelona, Tarragona and Tortosa). Anomalies are computed as percentages with respect to the average value of the period $1786-1850$.

\begin{tabular}{|c|c|c|c|c|c|c|c|c|c|c|c|c|}
\hline & \multicolumn{3}{|c|}{1 Location } & \multicolumn{3}{|c|}{2 Locations } & \multicolumn{3}{|c|}{3 Locations } & \multicolumn{3}{|c|}{4 Locations } \\
\hline & $<100 \%$ & $>100 \%$ & Mean \% & $<100 \%$ & $>100 \%$ & Mean \% & $<100 \%$ & $>100 \%$ & Mean \% & $<100 \%$ & $>100 \%$ & Mean $\%$ \\
\hline Winter & 8 & 3 & $90.6 \%$ & 2 & 0 & $72.5 \%$ & 6 & 0 & $28.9 \%$ & 1 & 0 & $9.3 \%$ \\
\hline Spring & 3 & 8 & $122.9 \%$ & 5 & 4 & $109.5 \%$ & 4 & 2 & $71.3 \%$ & 2 & 0 & $29.8 \%$ \\
\hline Summer & 8 & 0 & $49.8 \%$ & 3 & 0 & $61.5 \%$ & & & & & & \\
\hline Autumn & 9 & 2 & $89.6 \%$ & 0 & 1 & $115.8 \%$ & & & & & & \\
\hline
\end{tabular}

Table 3. Number of years when a rogation is celebrated when less $(<100 \%)$ or more $(>100 \%)$ precipitation than long term mean precipitation value is registered and precipitation mean anomaly in Cadiz, Gibraltar and Zafra for years with rogations celebrated simultaneously in 1 or 2 locations (Seville and Zafra). Anomalies are computed as percentages with respect to the average of the period 1805-1850 for Cádiz, 1790-1850 for Gibraltar and 1750-1840 for Zafra.

\begin{tabular}{|c|c|c|c|c|c|c|c|}
\hline & & \multicolumn{3}{|c|}{1 Location } & \multicolumn{3}{|c|}{2 Locations } \\
\hline & & $<100 \%$ & $>100 \%$ & Mean \% & $<100 \%$ & $>100 \%$ & Mean \% \\
\hline \multirow{3}{*}{ Winter } & Cádiz & 10 & 2 & $56.46 \%$ & $*$ & $*$ & $*$ \\
\hline & Gibraltar & 12 & 0 & $55.97 \%$ & $*$ & $*$ & $*$ \\
\hline & Zafra & 14 & 0 & $47.44 \%$ & $*$ & $*$ & $*$ \\
\hline \multirow{3}{*}{ Spring } & Cádiz & 10 & 5 & $95.60 \%$ & 2 & 0 & $46.17 \%$ \\
\hline & Gibraltar & 9 & 5 & $95.20 \%$ & 1 & 1 & $78.10 \%$ \\
\hline & Zafra & 12 & 7 & $93.60 \%$ & 5 & 2 & $78.30 \%$ \\
\hline \multirow{3}{*}{ Summer } & Cádiz & 1 & 0 & $0.00 \%$ & $*$ & $*$ & $*$ \\
\hline & Gibraltar & 1 & 0 & $0.00 \%$ & $*$ & $*$ & $*$ \\
\hline & Zafra & 0 & 1 & $327.75 \%$ & $*$ & $*$ & $*$ \\
\hline \multirow{3}{*}{ Autumn } & Cádiz & 7 & 5 & $88.50 \%$ & 1 & 0 & $24.46 \%$ \\
\hline & Gibraltar & 8 & 2 & $74.53 \%$ & $*$ & $*$ & $*$ \\
\hline & Zafra & 10 & 8 & $89.51 \%$ & 1 & 0 & $19.38 \%$ \\
\hline
\end{tabular}

but the temporal distribution has not matched the crop requirements. However, precipitation is well below its mean value in those years when rogations show a regional character (three or four locations with rogations simultaneously), showing a general lack of water over the whole region.

Both in winter and in spring, it is evident that the number of locations celebrating rogations increases simultaneously with the mean precipitation deficit in Barcelona. Thus, when droughts are identified in several locations simultaneously it is reasonable to assume the occurrence of an extended meteorological drought.

During the instrumental period, the maximum number of simultaneous rogation celebrations in summer is two. All the years with rogations in summer have lower precipitation than normal but, surprisingly, this anomaly is lower when rogations are celebrated in a single location than when they are celebrated in two locations. This is probably due to the very local character of summer convective precipitations over this region.
Finally, during autumn, the only year when two locations celebrated rogations simultaneously, a deficit of precipitation was recorded in Barcelona lower than the eleven years when rogations were celebrated in a single location. This is probably a problem with the size of the sample and, most probably, if more years were available the precipitation deficit would increase with the number of locations celebrating rogations, like in spring and winter.

\subsection{South-western region}

There are two rogation series (Seville and Zafra) to study droughts over this region and can be compared against two instrumental (Cadiz and Gibraltar) and one observational (Zafra) precipitation series.

Table 3 includes a summary of the precipitation anomalies in those years when rogations were celebrated only in one site or simultaneously at the two sites. As in Table 2, spring precipitation anomalies are smaller than in any other 


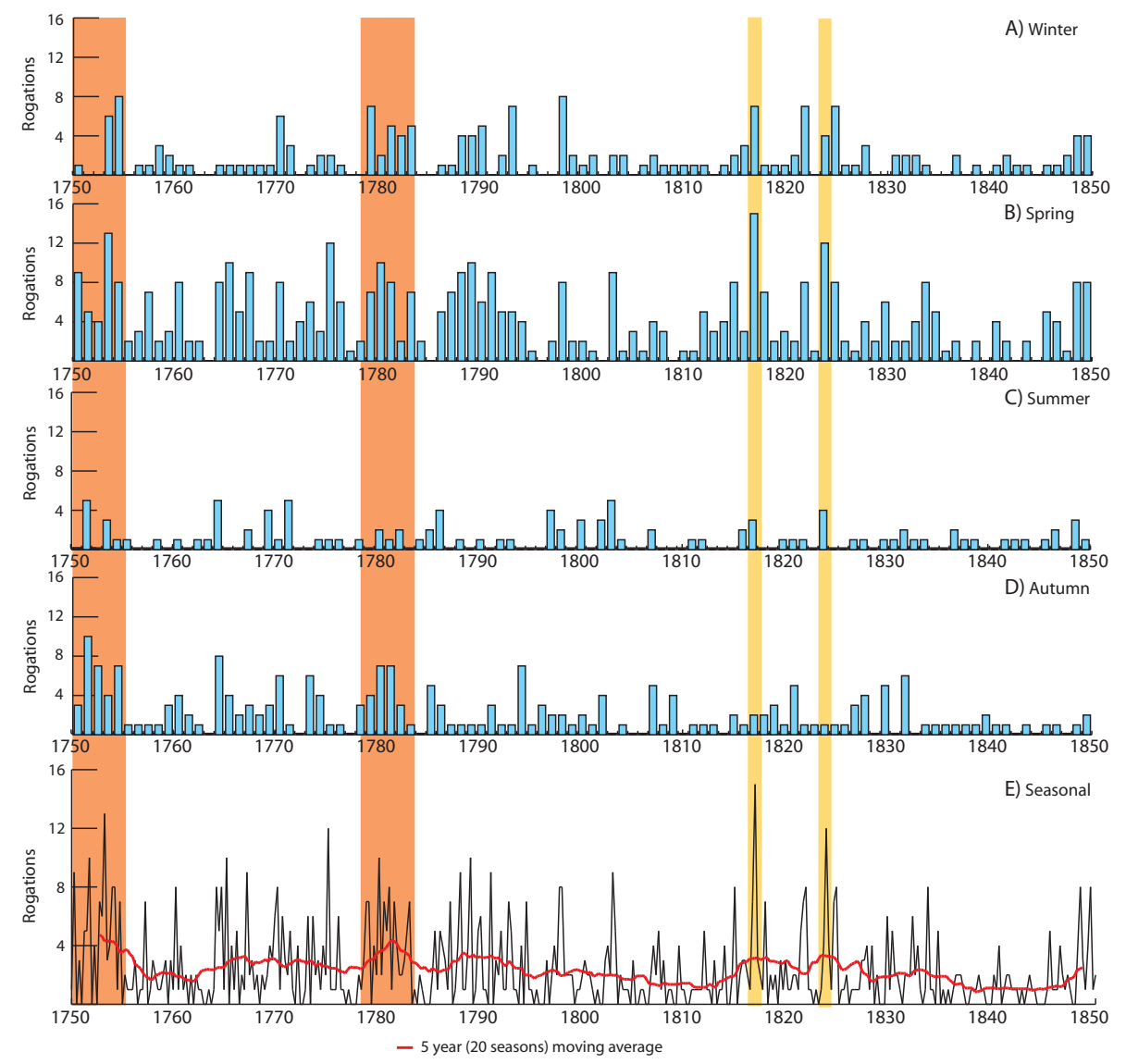

Fig. 3. Number of sites with rogations in winter (A), spring (B), summer (C), autumn (D) and complete seasonal time series (E). Highlighted specially dry periods (orange) and years (yellow).

season. Again, the precipitation anomaly observed is much higher whenever rogations are celebrated in both sites simultaneously. This time, having three different observational series, we can see that mean precipitation anomalies at the three sites are quite similar both when rogations were celebrated in one or in two sites, with the exception of summer.

As a summary, for both regions it has been observed that:

1. Spring is the season when the hydrological deficit needed to celebrate a rogation is lowest.

2. The higher the number of locations with rogations in a certain region, the higher the hydrological deficit recorded. Thus, the celebration of rogations in more than one site indicates not only a drought over a bigger area, but a more intense drought over all the affected sites.

Thus, this study will focus on the analysis of the most extended droughts to avoid some of the uncertainties associated to the individual occurrences and those described in Sect. 2.

\section{Analysis of regional patterns of extreme droughts}

Figure 3 includes the evolution in the number of sites with rogations celebrated along the same season every year (up to 16), both seasonally (Fig. 3a-d) and the complete series (Fig. 3e). Two periods are particularly noticeable, 17501754 and 1779-1782, when a high number of sites celebrated rogations simultaneously during several consecutive seasons, being the only periods with a high number of rogations in winter spring and autumn. 1817 is also a remarkable year, particularly in spring, with the highest number of sites with rogations in a single season for all the series, with simultaneous rogations in 15 of the 16 possible sites. Finally, 1824 is analyzed because it shows a drought pattern similar to that of 1817. These periods will be discussed in detail.

\subsection{Period: $\mathbf{1 7 5 0 - 1 7 5 4}$}

It is a short period but it has to be considered as a continuous extreme drought since all the years have a high number of rogations.

Figure 4 includes all the seasons during this period when rogations were celebrated in any of the 16 sites studied. In 


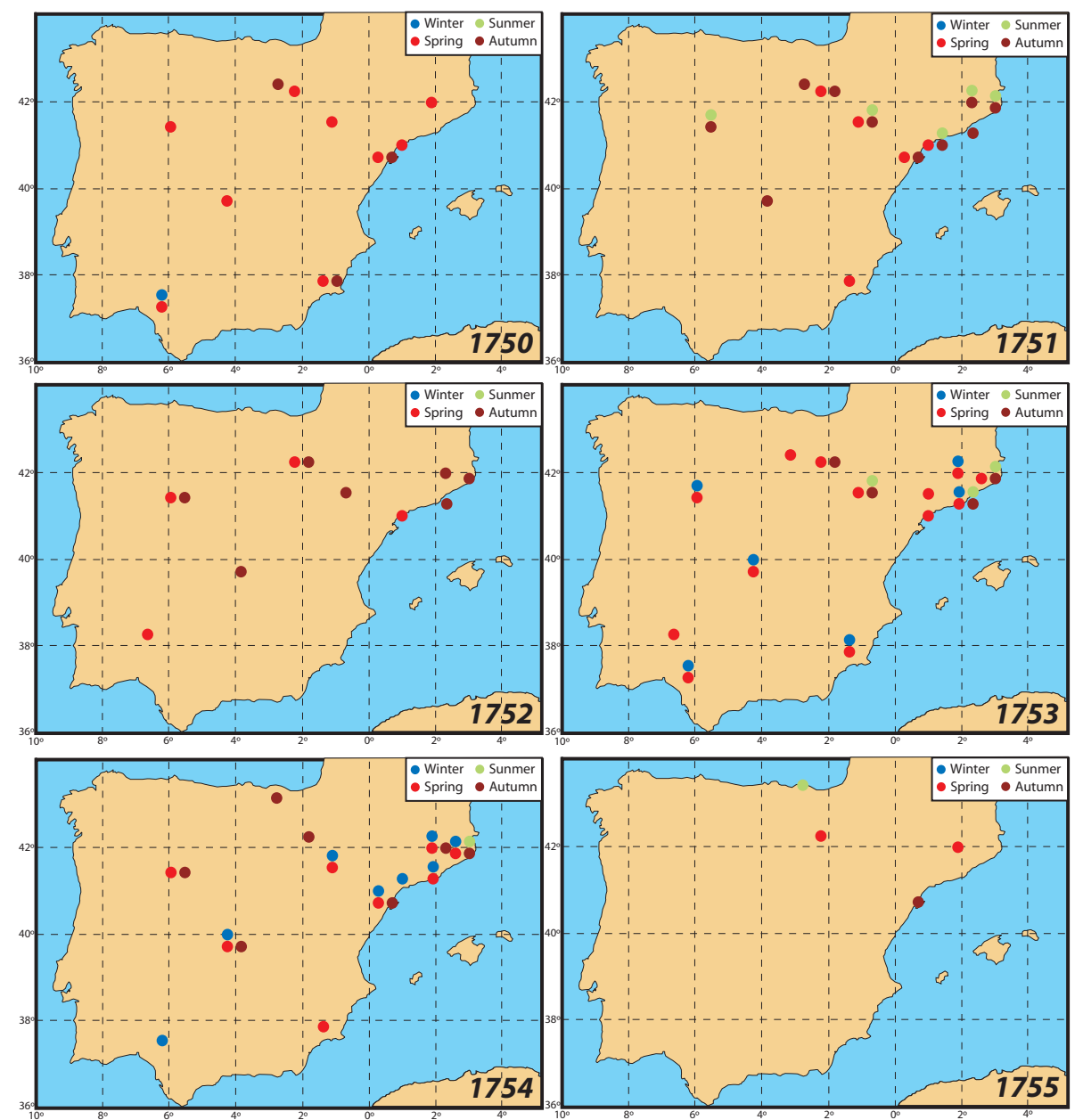

Fig. 4. Geographical distribution of rogations celebrated in Spain between 1750 and 1755.

1750 , rogations were celebrated in spring all over Spain, while in autumn there were rogations only in the Ebro valley and in winter only in Seville. In 1751, the drought is especially severe in the northern part of the peninsula, with rogations in many sites in spring, summer and autumn. In the southern half of the peninsula, the only rogations registered are in Murcia during spring. In 1752 the drought continues over the northern half of Spain but it is not so severe, as can be deduced from the fact that far fewer sites celebrated rogations and that most of them were only during one season (autumn or spring). Rogations in southern Spain are scarce and only Zafra has one celebration during spring. In 1753, the area affected by the drought expands and many rogations are registered during winter and spring. The drought is more severe over the north-eastern area of the peninsula, with celebration of rogations in summer and autumn. This is the only year in the whole series when Barcelona recorded rogations in the four seasons. The situation in 1754 remains very much the same as the previous year, with a severe drought over the whole peninsula, but more intense in the northern half where many rogations were celebrated in winter, spring and autumn. Again, there is a site where rogations were registered during the four seasons, Gerona (and again, only year in the whole series). In the southern part of the Peninsula, only Seville (winter) and Murcia (spring) celebrated rogations. In 1755 the drought came to its end and only some sites celebrated rogations during different seasons of the year. It is most probable that 1755 was a rainy year, particularly during winter, since it was capable of solving the effects of the previous four years.

It is easy to find other documentary references to the drought all over the Peninsula in other non-ecclesiastical archives as local papers, particular correspondence or other secondary sources. Some of these references make it very clear how rigorous the drought was: "1753 was a horrible year for the countryside. No crop at all. There was even a notable loss of livestock. The year after, the treasury helped with the sowing. People were in absolute misery." (Álvarez Sáenz de Buruaga, 1994). 

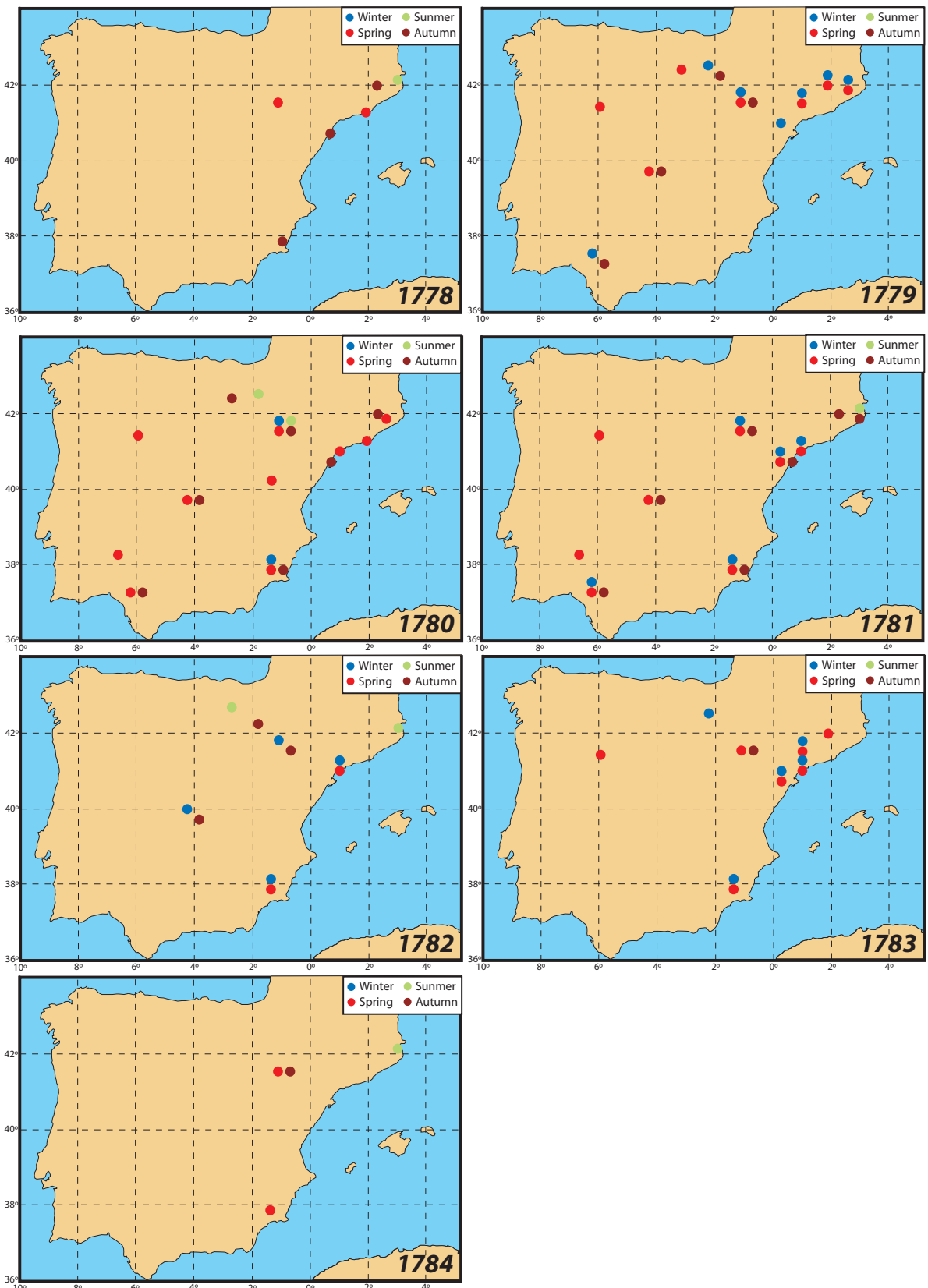

Fig. 5. Geographical distribution of rogations celebrated in Spain between 1778 and 1784.

The drought was really causing a tremendous famine, as stated in a letter from Benjamin Keene (Ambassador of the UK in Spain in 1729-1739 and 1748-1757) to Abraham Castres (Ambassador of the UK in Portugal between 1749 and 1757) dated from 25 May 1753: "we are absolutely dry due to the high temperatures and this is the 3rd consecutive year without rain. We have private reserves of wheat for this year but if it is like this one, a crisis will start. There are riots in Madrid with people asking for bread..." (Lodge, 1933).

\subsection{Period: $\mathbf{1 7 7 9 - 1 7 8 2}$}

Figure 5 shows the development of this drought in the early 1780s. In 1778 almost no rogations were celebrated, only a few of them in the Mediterranean coasts and mostly during autumn. In 1779 the drought starts its expansion all over Iberia with the exception of the south-eastern areas. Rogation celebrations are much more notable in winter and spring, even when during autumn there are records or rogations in the Ebro valley, Toledo and Seville. In 1780 the drought is evident across the peninsula, including the SE 
areas. Rogations are celebrated mostly in spring and autumn, although there are some sites, like Zaragoza, where rogations were celebrated in every season (only year in the complete series), or Murcia, where there were rogation in all seasons but summer. In 1781 rogations stop in the north of the peninsula but there are up to 4 locations (Seville, Murcia, Zaragoza and Tortosa) where rogations are celebrated in winter, spring and autumn. In 1782 the number of rogations is highly reduced and no clear seasonal pattern is discernible. Apparently, only the eastern part, particularly the Ebro valley, seems to continue under the effect of the drought. In 1783 most of the celebrations of rogations are in winter and spring and are concentrated in the Ebro valley. Outside this valley, only Murcia and Zamora celebrate some rogations. Finally, in 1784 the drought is over and only Zaragoza, Murcia and Gerona celebrate some rogations.

\section{$5.3 \quad$ Year 1817}

The drought in 1817 is particularly interesting due to several reasons. First, it is the drought with the highest number of rogations celebrated in a single year in the whole series. Second, it is during this year when the eruption of the Tambora (1815) was most intensely affecting the rainfall over the Iberian Peninsula.

Prohom (2003) studied the impact that recent volcanic eruptions had in the precipitation recorded in the Iberian Peninsula and concluded that the first two winters following a major eruption show extended rainfall deficits. In contrast, the central Mediterranean coast tends to concentrate positive anomalies in some post-volcanic winter months. As a whole, the two first post-volcanic autumns seem to be drier in most of the Mediterranean fringe, the southeast being the most affected region by this response. The magnitude of the eruptions and the total length of negative anomalies of precipitation may be correlated. The summer is the only season recording more frequent positive precipitation anomalies.

Trigo et al. (2009) studied specifically the impact of the Tambora over the climate of the Iberian Peninsula and, regarding precipitation, they concluded that the most notable impacts were positive precipitation anomalies in the summer of 1816 and very negative precipitation anomalies in 1817 although, as the authors point out: "A comprehensive analysis on precipitation anomalies is harder to perform owing to the scarce data availability and the large spatial variability that characterizes Iberian precipitation regime".

It seems reasonable to think that the new documentary evidences presented in this paper, together with the possibility of evaluating the impact of the Tambora within a framework of 101 years can improve the knowledge about the impacts of this eruption over precipitation in Iberia.

Tambora erupted in the island of Sumbaya (Indonesia) on 10 April 1815 (Sigurdsson and Carey, 1992). Even if it is assumed that it is not related with the eruption of the Tambora, this year the whole Iberian Peninsula was affected by a spring drought (Fig. 6), a little bit more severe over the coastal areas, where rogations were celebrated in winter (Barcelona and Murcia). Droughts were also recorded in autumn in Murcia and Seville. However, in 1816, when the Tambora impact over the summer temperature in the Iberian peninsula was most intense (Trigo et al., 2009), precipitation was probably abundant since rogations ceased over most of the peninsula, with only a few celebrations in the Mediterranean coasts but without a clear seasonal pattern. Then, 1817 appeared as the year with the most intense spring drought in the whole 101 years series, with rogations celebrated in every site but Bilbao. This year was particularly dry in the Mediterranean coasts, where many locations celebrated rogations in winter and continued in summer and/or autumn. Vic is noticeable because rogations were celebrated all the seasons for the only period of the whole series. In 1818 the drought only remains in the east, with rogations mostly in spring. And in 1819 , Murcia is the only site where the drought remains active and rogations are celebrated in every season of the year but summer.

As a summary it can be said that the most notable impacts of the Tambora are: the intense drought identified in Spain during 1817 , particularly during spring, when the most extended drought of the series is detected; and the low number of rogations celebrated in 1816, specially considering that 1815 and 1817 were years with rogation celebrations all over the peninsula.

\subsection{Year 1824}

Figure 7 includes the differences in the number of spring rogations between two consecutive years. This index shows the jump from wet to a dry spring conditions.

There are two events when these differences are highest: 1817/1816 (related to Tambora eruption) shows up as the year with the highest difference in the whole series, but it is very closely followed by $1824 / 1823$, which could have been affected by the eruption of the Galunggung (Indonesia) on 8 October 1822 (with a VEI - Volcanic Explosivity Index - of 5) (Bronto, 1989) and/or the eruption of the Usu (Hokkaido, Japan; VEI 4), which occurred sometime between march and October of that same year (Jousset et al., 2003).

There are evident resemblances between Figs. 6 and 8, where the spatial pattern of the celebration of rogations the years after the eruptions of Tambora (Fig. 6) and Galanngung (Fig. 8) are shown. In 1822, Galanngung eruption, there were spring and winter droughts the Iberian Peninsula, mostly in the Mediterranean coasts and in the Ebro valley. Those droughts came suddenly to an end in 1823 , when rogations were celebrated only in Vic (spring) and Murcia (autumn) and this year was particularly good for crop production. In 1824, the Iberian Peninsula is characterized by a much extended drought, especially in spring, and in the NE areas in summer and autumn. In 1825 the drought continues 


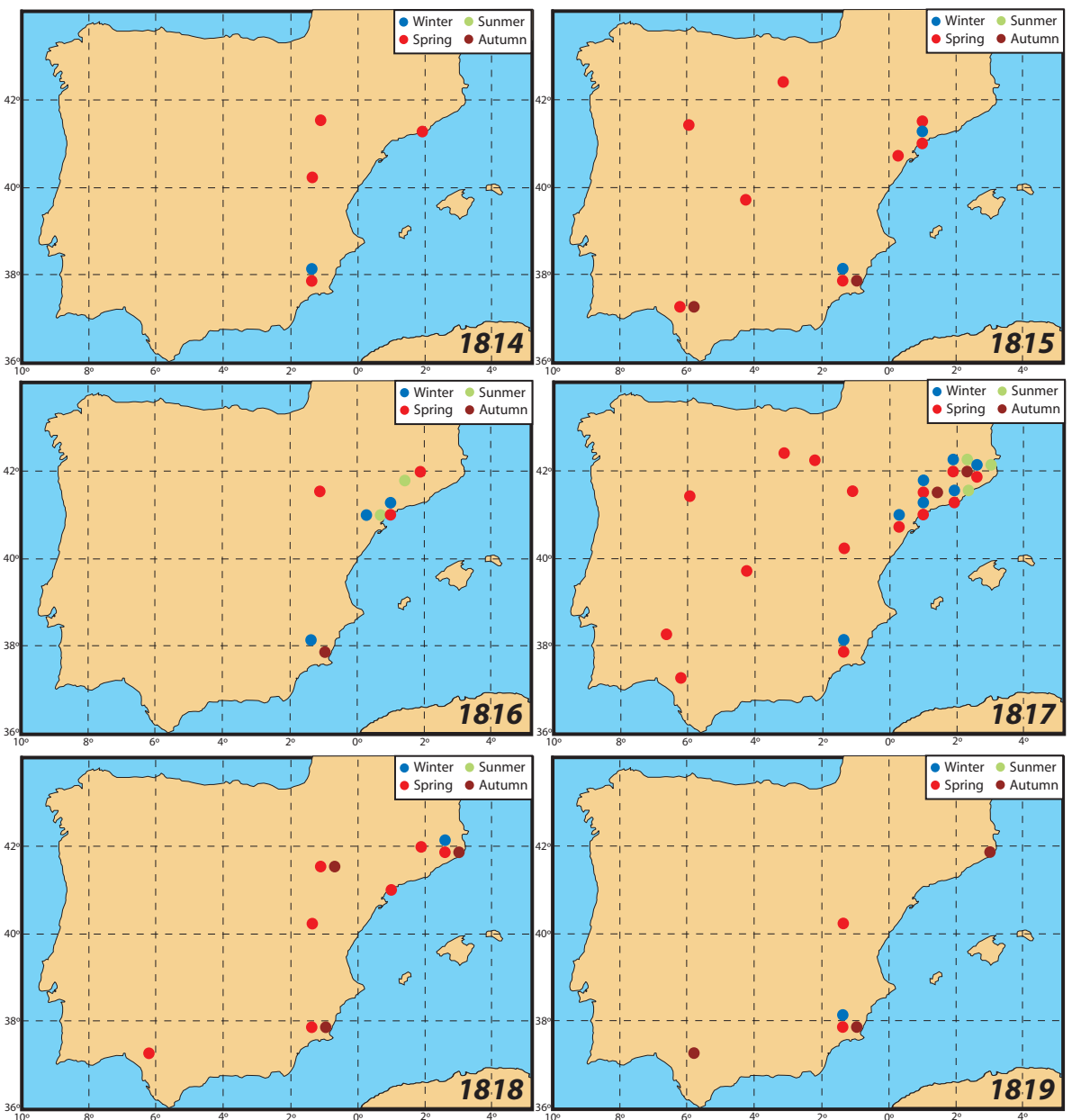

Fig. 6. Geographical distribution of rogations celebrated in Spain between 1814 and 1819.

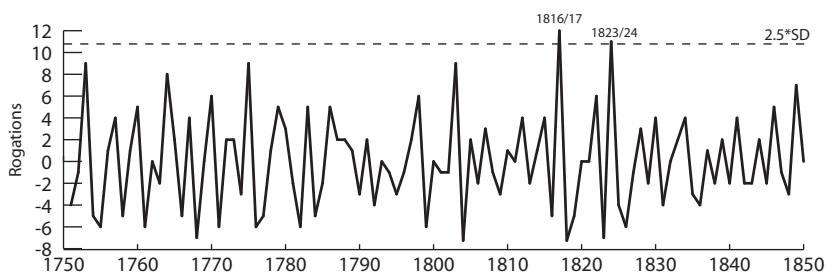

Fig. 7. Difference in the number of spring rogations between two consecutive years.

being Peninsular-wide in winter and spring, though not as intense as the year before, and far fewer rogations are celebrated in the second part of the year. In 1826 there were some rogation celebrations only in Seville and Murcia.

\subsection{Comparison between droughts identified from rogation series and other information sources about precipitation}

In order to analyze how other proxies or instrumental series identify the drought events presented, Fig. 9a shows the evolution of the annual precipitation of the three available precipitation series (Cadiz, Gibraltar and Barcelona), the annual evolution of the observational series in Zafra and in other high resolution proxies available for this period in the Iberian peninsula built from documentary sources for Andalusia (Rodrigo et al., 1999, 2000) and for the south of Portugal (Taborda et al., 2004).

Regarding those years with droughts influenced by volcanic activity in 1817 and 1824, all the instrumental series show that those years had precipitations lower than average, especially in Barcelona and Cadiz where precipitation records are among the driest in the whole series. The Zafra observational series also shows those years among the driest in the series. It is only in the documental series reconstructed for Andalusia where a positive anomaly of the precipitation 


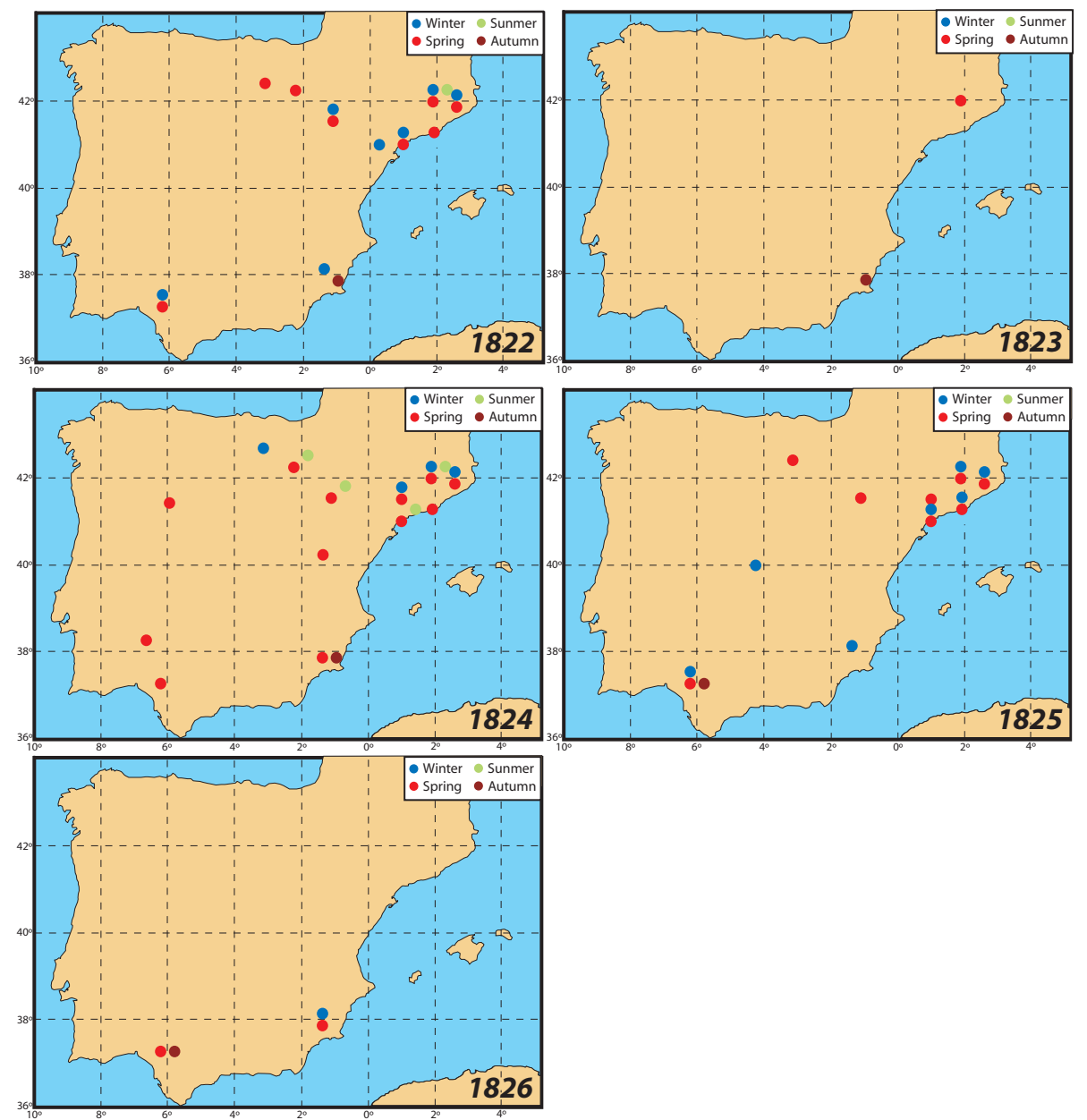

Fig. 8. Geographical distribution of rogations celebrated in Spain between 1822 and 1826.

can be found in 1817; precipitation in 1824 was considered as normal (index equal to cero, no precipitation anomalies detected).

There is no instrumental information about the two periods with long lasting droughts, but Fig. 9a shows that Zafra series is characterized by normal values during the 1750-1754 period, even if the index value in those years is lower than its value in the following $4 \mathrm{yr}$, just before the first gap in this series. However, both in Andalusia and in the South of Portugal all these years can be considered as a dry period, with some of the lowest values in the whole series in both cases.

During the second dry period, 1779-1783, all the observational and proxy records are in better concordance with the characteristics of a long lasting drought with the exception of the last year. But even this result is in concordance with results obtained with rogations series, since it was noticed that in 1783 the drought was confined largely to northeastern Iberia and all this observational and proxy records are situated in the south-eastern part of the peninsula. The early meteorological series from Lisbon and Mafra (western Iberian Peninsula) are in agreement with this result, showing a dry period from 1779 to 1782 (with the exception of spring 1782), followed by two wet years 1783 and 1784 (Alcoforado et al., 2012).

The analysis of other precipitation series characterizing regions near the Iberian peninsula, but not in the peninsula itself, show that all the droughts periods identified in the Iberian peninsula were also characterized by negative anomalies in the precipitation in Morocco in the reconstruction made by Esper et al. (2007). On the other hand, the reconstruction of the precipitation series of the western European sector, by Pauling et al. (2006), shows 1750-1754 and 1779-1783 with precipitation below normal values, but 1817 and 1824 appear as very close to the average precipitation.

\section{Conclusions}

Sixteen rogation series covering the period $1750-1850$ in Spain (available at http://salva-sinobas.uvigo.es/index.php/ eng/) have been analysed. The overlapping with instrumental precipitation series from Barcelona, Gibraltar and Cadiz and 

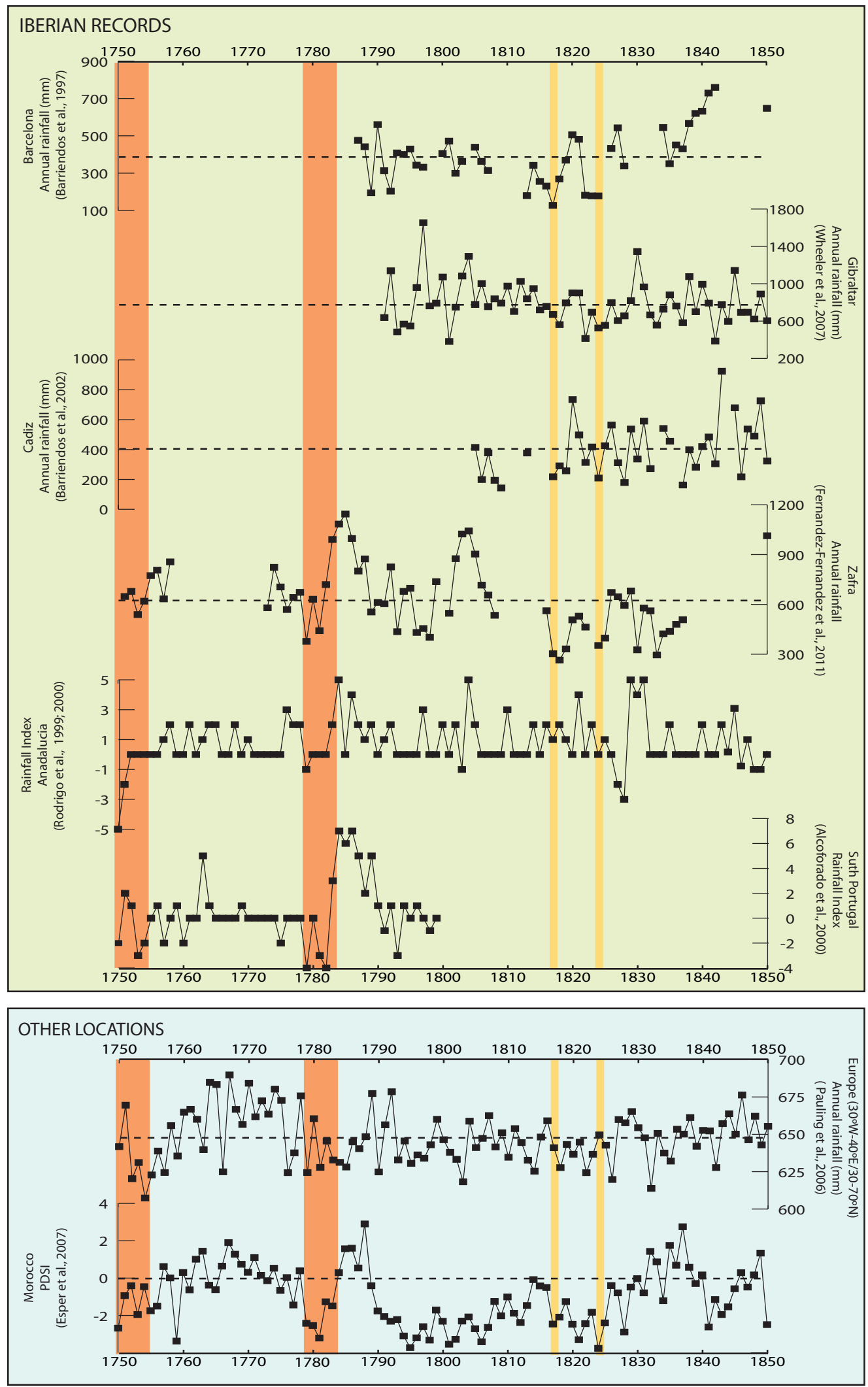

Fig. 9. Evolution of some instrumental, observational and proxy precipitation series in the Iberian Peninsula (upper panel) and outside the Iberian Peninsula (lower panel). 
an observational series from Zafra, served to identify some characteristics of rogation ceremonies that one has to keep in mind when using rogation series as a precipitation proxy: (a) the precipitation deficit needed to celebrate a rogation is much lower in spring than in any other season; (b) the hydrological deficit in the sites of a particular region increases with the number of sites (within that particular region) where rogations are celebrated simultaneously.

The analysis of the rogations series shows that 1750-1754 and 1779-1783 are probably the driest periods in the 101 analyzed years. Both periods are characterized by a high number of rogations in all the seasons of the year in IP and both show dry conditions in the surrounding regions (Morocco and Western Europe). This pattern of dry conditions in IP, Morocco and much of Europe have been recognised in previous observational studies, as the drought 2004/2005 (García-Herrera et al., 2007) or the actual drought of Europe (2011/2012), caused by Atlantic blocks and periods with high pressures located in the west of the United Kingdom, configurations that reduce cyclones track over Iberia and Western Europe.

The most extended seasonal drought in the complete period is identified during the spring of 1817 , when all the sites but Bilbao celebrated rogation. This drought was apparently caused by the eruption of the Tambora in 1815 . The spring drought detected in 1824, again among the most extended detected in the analyzed period, could be thought to be partly caused by the eruptions of Galunggung (Indonesia) and Usu (Japan), but this relationship has to be studied in more detail in future analysis. Both droughts are evident in the instrumental, observational and proxy series available in the Iberian Peninsula and extends to the south, including Morocco, not to the north and it is not evident at European level. This pattern is in agreement with previous analysis showing the link of the tropical volcanic eruptions with positive phases of the North Atlantic Oscillation during the first and second post-eruption years, leading to wetter conditions over Northern Europe and drier in the IP and Morocco (Fischer et al., 2007).

\section{Appendix A}

\section{Documentary sources consulted to generate the new rogations series}

Calahorra

Calahorra Cathedral Archives

- Actas Capitulares del Archivo Catedralicio y

Diocesano de Catedral de Calahorra, 1451-1913, 35 vols.

Teruel

Teruel Cathedral Archives

- Actas Capitulares del Archivo de la Santa Iglesia-

Catedral de Teruel, 1604-1928, 28 vols.

Zafra

Zafra City Archives

Estado de Feria, Sección Gobierno, Serie Consultas y

Decretos, 1741-1840.

Estado de Feria, Sección Administración, Memoriales, instancias e informes, 1772-1840.

Notarial, Sección Protocolos, Serie Zafra, Escribano Pedro García Pardo 1773, 1775, 1780, 1781, 1782, 1789.

Municipal, Sección Gobierno, Libro de Acuerdos Municipales, año 1794 y 1803.

Nuestra Señora de la Candelaria Archives Libro de Acuerdos de la Mesa Capitular, años 1712-1767 and 1801-1836.

Libro de defunciones, vols. 9 (1742-1766), 10 (1738-1754), 12 (1782-1802).

Libro de fábrica de la Colegial, 1719-1761.

Libro de cuentas de la Mesa capitular, 1753-1755.

Libro de hermanos de la cofradía de San Diego, 1602-1832.

Libro de la cofradía de la Cruz de la calle Badajoz, 18 th century.

Libro de la hermandad del Santo Entierro, 1720-1808.

Correspondencia, leg. 2, docs. 1 and 2.

Santa Clara de Zafra Convent Archives

Sección Vida común, Serie Relatos y composiciones:

Noticias de las traslaciones que ha tenido la Sma. y milagrosa imagen de Nra. Sra. del Valle. 
Acknowledgements. Authors are grateful to D. Wheeler who provides rainfall data from Gibraltar. This work has been financed by the Ministry of the Environment, Rural and Maritime Affairs of Spain "Salvà-Sinobas project: Climatic Variability Characterization in the Iberian Peninsula during the Period 1750-1850" (ref. 200800050083542), Spanish Science and Innovation Ministry (AYA2008-04864/AYA and AYA2011-25945) and MILLENNIUM Project (European Commision, IP 017008-2).

Edited by: D. Wheeler

\section{References}

Alcoforado, M. J., Nunes, M. F., Garcia, J. C., and Taborda, J. P.: Temperature and precipitation reconstruction in southern Portugal during the late Maunder Minimum (1675-1715), Holocene, 10, 333-340, 2000.

Alcoforado, M. J., Vaquero, J. M., Trigo, R. M., and Taborda, J. P.: Early Portuguese meteorological measurements (18th century), Clim. Past, 8, 353-371, doi:10.5194/cp-8-353-2012, 2012.

Álvarez Saenz de Buruaga, J.: Materiales para la historia de Mérida (de 1637 a 1936), Ayuntamiento de Badajoz, Badajoz, Spain, 363 pp., 1994.

Álvarez Vázquez, J. A.: Drought and Rainy Periods in the Province of Zamora in the 17th, 18th, and 19th Centuries, in: Quaternary Climate in Western Mediterranean, Universidad Autónoma de Madrid, Madrid, Spain, 221-233, 1986.

Barriendos, M.: Climatic variations in the Iberian peninsula during the late Maunder minimum (AD 1675-1715): an analysis of data from rogation ceremonies, Holocene, 7, 105-111, 1997.

Barriendos, M., Gómez, B., and Peña, J. C.: Old series of meteorological readings for Madrid and Barcelona (1780-1860) documentary and observed characteristics, in: Advances in historical climatology in Spain, oikos-tau, Barcelona, Spain, 157-172, 1997.

Barriendos, M., Martín-Vide, J., Peña, J. C., and Rodríguez, R.: Daily meteorological observations in Cádiz-San Fernando, Analysis of the documentary sources and instrumental data content (1786-1996), Climatic Change, 53, 151-170, 2002.

Bronto, S.: Volcanic geology of Galunggung, West Java, Indonesia, Ph.D. thesis, University of Canterbury, New Zealand, 490 pp., 1989.

Camuffo, D., Bertolin, C., Diodato, N., Cocheo, C., Enzi, S., Sghedoni, M., Barriendos, M., Dominguez-Castro, F., Garnier, E., Alcoforado, M. J., and Nunes, M. F.: 500-year precipitation reconstruction in the Western Mediterranean Basin by means of documentary data and instrumental observations, Climatic Change, in review, 2011.

Cuadrat, J. M. and Vicente-Serrano, S.: La sécheresse en Aragon à partir des archives des rogations (XVIe-XIXe S.), Rev. Climatol., 14, 44-50, 2002.

Cullen, H. M., deMenocal, P. B., Hemming, S., Hemming, G., Brown, F. H., Guilderson, T., and Sirocko, F.: Climate change and the collapse of the Akkadian empire: Evidence from the deep sea, Geology, 28, 379-382, 2000.

Curtis, J. H. and Hodell, D. A.: Climate variability on the Yucatan Peninsula (Mexico) during the past 3500 years, and implications for Maya cultural evolution, Quaternary Res., 46, 37-47, 1996.
deMenocal, P.: Cultural responses to climate change during the Late Holocene, Science, 292, 667-673, 2001.

Diffenbaugh, N. S., Pal, J. S., Giorgi, F., and Gao, X.: Heat stress intensification in the Mediterranean climate change hotspot, Geophys. Res. Lett., 34, L11706, doi:10.1029/2007GL030000, 2007.

Domínguez-Castro, F., Santisteban, J. I., Barriendos, M., and Mediavilla, R.: Reconstruction of drought episodes for central Spain from rogation ceremonies recorded at Toledo Cathedral from 1506 to 1900: A methodological approach, Global Planet. Change, 63, 230-242, 2008.

Domínguez-Castro, F., García-Herrera, R., Ribera, P., and Barriendos, M.: A shift in the spatial pattern of Iberian droughts during the 17th century, Clim. Past, 6, 553-563, doi:10.5194/cp-6-5532010, 2010.

Dong, X., Xi, B., Kennedy, A., Feng, Z., Entin, J. K., Houser, P. R., Schiffer, R. A., L'Ecuyer, T., Olson, W. S., Hsu, K., Liu, W. T., Lin, B., Deng, Y., and Jiang, T.: Investigation of the 2006 drought and 2007 flood extremes at the Southern Great Plains through an integrative analysis of observations, J. Geophys. Res., 116, D03204, doi:10.1029/2010JD014776, 2011.

Drysdale, R., Zanchetta, G., Hellstrom, J., Maas, R., Fallick, A., Pickett, M., Cartwright, I., and Piccini, L.: Late Holocene drought responsible for the collapse of Old World civilizations is recorded in an Italian cave flowstone, Geology, 34, 101-104, 2006.

Esper, J., Frank, D., Büntgen, U., Luterbacher, J., and Xoplaki, E.: Long-term drought severity variations in Morocco, Geophys. Res. Lett., 34, L17702, doi:10.1029/2007GL030844, 2007.

Esteban-Parra, M. J., Rodrigo, F. S., and Castro-Díez, Y.: Spatial and temporal patterns of precipitation in Spain for the period 1880-1992, Int. J. Climatol., 18, 1557-1574, 1998.

Estrela, M. J., Peñarrocha, D., and Millán, M.: Multi-annual drought episodes in the Mediterranean (Valencia Region) from 1950-1996, A spatio-temporal analysis, Int. J. Climatol., 20, 1599-1618, 2000.

Fernández-Fernández, M. I., Gallego, M. C., Domínguez-Castro, F., Vaquero, J. M., Moreno González, J. M., and Castillo Durán, $\mathrm{J}$.: Reconstruction of rainfall in Zafra (southwest Spain) from 1750 to 1840 from documentary sources, Clim. Past Discuss., 7, 3895-3918, doi:10.5194/cpd-7-3895-2011, 2011.

FEWSNET: Rwanda food security update, Technical report, Famine Early Warning System Network, 2005a.

FEWSNET: Africa: weather hazards assessment, Technical report, Famine early Warning System Network, 2005b.

FEWSNET: Rwanda food security update, Technical report, Famine Early Warning System Network, 2006a.

FEWSNET: Africa: weather hazards assessment, Technical report, Famine early Warning System Network, 2006b.

Fischer, E. M., Luterbacher, J., Zorita, E., Tett, S. F. B., Casty, C., and Wanner, H.: European climate response to tropical volcanic eruptions over the last half millenium, Geophys. Res. Lett., 34, L05707, doi:10.1029/2006GL027992, 2007.

Gallego, M. C., Trigo, R. M., Vaquero, J. M., Brunet, M., García, J. A., Sigró, J., and Valente, M. A.: Trends in frequency indices of daily precipitation over the Iberian Peninsula during the last century, J. Geophys. Res.-Atmos., 116, D02109, doi:10.1029/2010JD014255, 2011. 
García-Herrera, R., Paredes, D., Trigo, R. M., Trigo, I. F., Hernández, E., Barriopedro, D., and Mendes M. A.: The outstanding 2004-2005 drought in the Iberian Peninsula: associated atmospheric circulation, J. Hydrometeorol., 8, 483-498, 2007.

Haug, G. H., Gunther, D., Peterson, L. C., Sigman, D. M., Hughen, K. A., and Aeschlimann, B.: Climate and the collapse of Maya civilization, Science, 299, 1731-1735, 2003.

Hodell, D. A., Curtis, J. H., and Brenner, M.: Possible role of climate in the collapse of Classic Maya civilization, Nature, 375, 391-394, 1995.

Hodell, D. A., Brenner, M., Curtis, J. H., and Guilderson, T.: Solar forcing of drought frequency in the Maya Lowlands, Science, 292, 1367-1370, 2001.

Hodell, D. A., Brenner, M., and Curtis, J. H.: Climate and cultural history of the Northeastern Yucatan Peninsula, Quintana Roo, Mexico, Climatic Change, 83, 215-240, 2007.

Huntington, T. G.: Evidence for intensification of the global water cycle: Review and synthesis, J. Hydrol., 319, 83-95, 2006.

Jousset, P., Mori, H., and Okada, H.: Elastic models for the magma intrusion associated with the 2000 eruption of Usu volcano, Hokkaido, Japan, J. Volcanol. Geoth. Res., 125, 81-106, 2003

Kijazi, A. L. and Reason, C. J. C.: Analysis of the 1998 to 2005 drought over the northastern highlands of Tanzania, Clim. Res., 38, 209-223, 2009.

Lana, X. and Burgueño, A.: Some statistical characteristics of monthly and annual pluviometric irregularity for the Spanish Mediterranean cost, Theor. Appl. Climatol., 65, 79-97, 2000.

Lana, X., Martínez, M. D., Burgueño, A., Serra, C., Martín-Vide, J., and Gómez, L.: Spatial and temporal patterns of dry spell lengths in the Iberian Peninsula for the second half of the twentieth century, Theor. Appl. Climatol., 91, 99-116, 2008.

Lewis, S. L., Brando, P. M., Oliver, L. P., Geertje, M. F., van der Heijden M. F., and Nepstad, D.: The 2010 Amazon Drought, Science, 331, 554, 2011.

Lodge R.: The private correspondence of sir Benjamín Keene, edited with introduction and notes by Sir Richard Lodge, The University Press, Cambridge, 548 pp., 1933.

Lutherbacher, J., Xoplaki, E., Dietrich, D., Rickli, R., Jacobeit, J., Beck, C., Gyalistras, D., Schmutz, C., and Wanner, H.: Reconstruction of sea level pressure fields over the Eastern North Atlantic and Europe back to 1500, Clim. Dynam., 18, 545-561, 2002.

Marengo, J. A., Nobre, C. A., Tomasella, J., Oyama, M. D., Sampaio de Oliveira, G., de Oliveira, R., Camargo, H., Alves, L. M., and Foster Brown, I.: The Drought of Amazonia in 2005, J. Climate, 21, 495-516, 2008.

Martín-Vide, J. and Barriendos, M.: The use of rogation ceremony records in climatic reconstruction: a case study from Catalonia (Spain), Climatic Change, 30, 201-221, 1995.

Martín-Vide, J. and Gómez, L.: Regionalization of peninsular Spain based on the length of dry spells, Int. J. Climatol., 19, 537-555, 1999.

Moral Ruiz, J.: La agricultura española a mediados del siglo XIX (1850-1870), Resultados de una encuesta agraria de la época, Serie Estudios de la Secretaria General Técnica, Ministerio de Agricultura, Madrid, Spain, 1979.

Murphy, B. F. and Timbal, B.: A review of recent climate variability and climate change in southeastern Australia, Int. J. Climatol., 28, 859-879, 2008.
Nicoll, K.: Recent environmental change and prehistoric human activity in Egypt and Northern Sudan, Quaternary Sci. Rev., 23, 561-580, 2004.

Obasi, G. O. P.: WMO's Role in the international decade for natural disaster reduction, B. Am. MeteorOL. Soc., 75, 1655-1661, 1994.

Olcina, J.: Tipología de las sequías en España, Ería, 56, 201-227, 2001.

Paredes, D., Trigo, R. M., García-Herrera, R., and Trigo, I. F.: Understanding precipitation changes in Iberia in early spring: weather typing and storm-tracking approaches, J. Hydrometeorol., 7, 101-113, 2006.

Pauling, A., Lutherbacher, J., Casty, C., and Wanner, H.: Five hundred years of girded high-resolution precipitation reconstructions over Europe and the connection to large-scale circulation, Clim. Dynam., 26, 387-405, 2006.

Pérez-Cueva, A. J. and Escrivá, J. L.: Aspectos climáticos de las sequías en el ámbito mediterráneo, Cuadernos de Geografía, 30, 1-12, 1982.

Prohom, M.: Incident of large volcanic eruptions on the climate of Iberia and the Balearics, Ph.D. thesis, Universidad de Barcelona, Barcelona, Spain, 186 pp., 2003.

Rodrigo, F. S. and Barriendos, M.: Reconstruction of seasonal and annual rainfall variability in the Iberian Peninsula (16th20th Centuries) from documentary data, Global Planet. Change, 63, 243-257, 2008.

Rodrigo, F. S., Esteban-Parra, M. J., Pozo-Vázquez, D., and CastroDíez, Y.: A 500-year precipitation record in Southern Spain, Int. J. Climatol., 19, 1233-1253, 1999.

Rodrigo, F. S., Esteban-Parra, M. J., Pozo-Vázquez, D., and CastroDíez, Y.: Rainfall variability in southern Spain on decadal to centennial time scales, Int. J. Climatol., 20, 721-732, 2000.

Sáez de Ocáriz, M.: Climatología y régimen de lluvias en la rioja alta, Siglos XVI al XIX, Zubia, 8, 129-178, 1990.

Serrano, A., Mateos, V. L., and García, J. A.: Trend analysis of monthly precipitation over the Iberian Peninsula for the period 1921-1995, Phys. Chem. Earth B, 24, 85-90, 1999.

Sigurdsson, H. and Carey, S.: Eruptive history of Tambora volcano, Indonesia, in: The Sea of Mount Tambora, Mitt. Geol. Paleont. Inst. Univ. Hamburg Heft, Germany, 187-206, 1992.

Sousa, P. M., Trigo, R. M., Aizpurua, P., Nieto, R., Gimeno, L., and Garcia-Herrera, R.: Trends and extremes of drought indices throughout the 20th century in the Mediterranean, Nat. Hazards Earth Syst. Sci., 11, 33-51, doi:10.5194/nhess-11-33-2011, 2011.

Stothers, R. B.: The great Tambora eruption in 1815 and its aftermath, Science, 224, 1191-1198, 1984.

Taborda, J. P., Alcoforado, M. J., and Garcia, J. C.: Climate in southern Portugal in the 18th century, Reconstruction based on instrumental and documentary sources, Geo-Ecologia 2, tThis book may be accessed at: http://www.clima.org, Centro de Estudos Geográficos, Lisboa, Portugal, 211 pp., 2004.

Trenberth, K. E., Smith, L., Qian, T., Dai, A., and Fasullo, J.: Estimates of the global water budget and its annual cycle using observational and model Data, J. Hydrometeorol., 8, 758-769, 2007.

Trigo, R. M., Vaquero, J. M., Alcoforado, M. J., Barriendos, M., Taborda, J., García-Herrera, R., and Luterbacher, J.: Iberia in 1816, the year without a summer, Int. J. Climatol., 29, 99-115, 2009. 
Vaquero, J. M.: Historical sunspot observations: a review, Adv. Space Res., 40, 929-941, 2007.

Vicente-Serrano, S. M.: Spatial and temporal analysis of droughts in the Iberian Peninsula (1910-2000), Hydrolog. Sci. J., 51, 8397, 2006a.

Vicente-Serrano, S. M.: Differences in spatial patterns of drought on different time scales: an analysis of the Iberian Peninsula, Water Resour. Manage., 20, 37-60, 2006b.

Vicente Serrano, S. M. and Cuadrat, J. M.: North Atlantic oscillation control of drought in north-east Spain: evaluation since 1600 A.D., Climatic Change, 85, 357-379, 2007.

Vicente-Serrano, S. M. and López-Moreno, J. I.: The influence of atmospheric circulation at different spatial scales on winter drought variability through a semi-arid climatic gradient in northeast Spain, Int. J. Climatol., 26, 1427-1453, 2006.
Weiss, H., Courty, M. A., Wetterstrom, W., Guichard, F., Senior, L., Meadow, R., and Curnow, A.: The genesis and collapse of third millennium North Mesopotamian civilization, Science, 261, 995-1004, 1993.

Weiß, M., Flörke, M., Menzel, L., and Alcamo, J.: Model-based scenarios of Mediterranean droughts, Adv. Geosci., 12, 145-151, doi:10.5194/adgeo-12-145-2007, 2007.

Wheeler, D.: The Gibraltar climatic record: Part 2 Precipitation, Weather, 62, 99-105, 2007.

WMO 2012: http://www.wmo.int/pages/mediacentre/news/RCOF_ en.html last access: 9 March 2012.

Yoshiyuki Kondo, A.: Estudio cuantitativo de la evolución del sector agrario español de 1750 a 1900, Ph.D. thesis, Universidad Autónoma de Madrid, Madrid, Spain, 352 pp., 1983.

Zamora, R.: El final de la pequeña edad de hielo, Publicaciones Universidad de Alicante, Alicante, Spain, 194 pp., 2002. 